\title{
Cosmology in the book of Revelation
}

\begin{abstract}
Author:
Gert J.C. Jordaan ${ }^{1}$

Affiliation:

${ }^{1}$ Faculty of Theology, North-

West University, South Africa

Correspondence to:

Gert Jordaan

Email:

gert.jordaan@nwu.ac.za

Postal address:

PO Box 147, North-West

University 2520, South Africa

Dates:

Received: 14 Feb. 2013

Accepted: 16 July 2013

Published: 05 Nov. 2013

How to cite this article:

Jordaan, G.J.C., 2013,

'Cosmology in the book of

Revelation', In die Skriflig/

In Luce Verbi 47(2), Art.

\#698, 8 pages. http://dx.doi.

org/10.4102/ids.v47i2.698
\end{abstract}

\section{Copyright:}

(C) 2013. The Authors.

Licensee: AOSIS

OpenJournals. This work

is licensed under the

Creative Commons

Attribution License.
Read online:
The cosmology of the book of Revelation mainly involves God's restored reign over the created

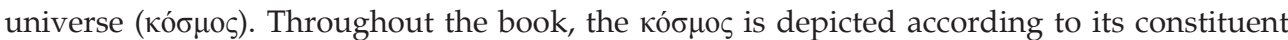
parts, namely heaven, sea and earth. At first sight, this threefold description seems to stem from the ancient Jewish and mythological three-storied cosmological view of 'up-above', 'here-below' and 'down-under'. However, this correspondence proves to be only superficial. Heaven is used by John not as much in spatial sense as in temporal sense: as symbolic reference to a divine point above time and history. Heaven is also a qualitative reference to a situation of complete obedient worship to God. Earth in John's visions is mostly used as metaphor for sinful mankind under the rule of Satan. Yet, the earth remains part of God's creation under his divine authority, and even becomes a refuge for the church in this dispensation. The sea in Revelation, when not denoting a physical space, is often equated by scholars to the abyss or the underworld. However, in Revelation the sea is mostly used as metaphor for the basic evil from which the beast originates and of everything immoral and impure. The last chapters of Revelation reveal that in the eschaton heaven, sea and earth will all be part of the new creation - renewed to the point where God's reign is restored and acknowledged above all doubt

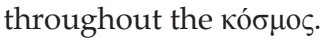

Kosmologie in die boek van Openbaring. Die kosmologie van Openbaring getuig van God se

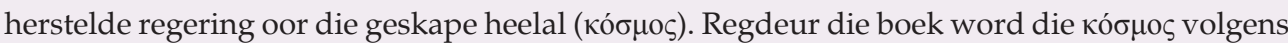
sy samestellende dele beskryf, naamlik hemel, see en aarde. Oppervlakkig beskou, lyk hierdie beskrywing na die antieke Joodse en mitologiese drie-verdieping-kosmologie van 'daar bo', 'hier onder' en 'daar onder'. Hierdie ooreenkoms is egter slegs oppervlakkig. Hemel word deur Johannes nie soseer in ruimtelike sin gebruik nie, maar in temporele sin: as simboliese verwysing dat God bo tyd en geskiedenis verhewe is. Hemel is ook 'n kwalitatiewe verwysing na 'n toestand van volmaakte gehoorsame aanbidding van God. Desgelyks word aarde meestal gebruik as metafoor vir 'n sondige mensdom onder Satan se heerskappy. Tog bly die aarde deel van God se skepping onder sy goddelike heerskappy, en word dit selfs aangetoon as 'n toevlugsoord vir die kerk in hierdie bedeling. Waar die see in Openbaring nie na 'n fisiese verskynsel verwys nie, word dit dikwels deur biblioloë op gelyke vlak met die diep put of die onderwêreld gestel. Johannes gebruik die see egter meestal as metafoor vir die boosheid waaruit die dier sy oorsprong het, asook vir alles wat sondig en onrein is. Openbaring 21 en 22 maak bekend dat hemel, see en aarde in die eschaton deel sal wees van die nuwe skepping -

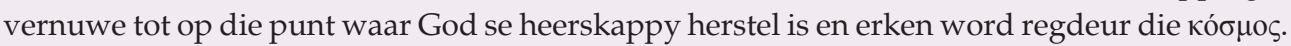

\section{Introduction}

An investigation into the cosmology in Revelation immediately involves the question whether the book really harbours a cosmology in the normal sense of the word, such as other books of the New Testament. The apocalyptic visions, as described in Revelation, picture a world that seems to be so far removed from the world known to mankind that one can hardly speak of a normal worldview or cosmology. Yet, it has to be accepted that the author of Revelation ${ }^{1}$ described the visions he saw from the viewpoint of his own cosmology in such a way that it could be understood by his first century audience (cf. Beale 1999:66-68; Barr 2003:63). Accordingly, modern scholarship generally has a more or less socio-historical approach to the cosmology of Revelation, resulting in a portrayal of the cosmological views of John and his audience. So the general notion is that the author of Revelation subscribed to the ancient Jewish cosmology, with a three-tiered cosmic division of heaven, earth and underworld (e.g. Osborne 2002:264; Aune 2006:51-52). This worldview would also perfectly fit the ancient mythological three-storied cosmological

1.In this article, the author of Revelation is accepted to have been the apostle John in agreement with the arguments of inter alia Kistemaker (2004:2-79) 
view of up-above, here-below and down-under, as formerly suggested by Bultmann (1966:15).

However, attempts to equate John's description of the cosmos to any ancient mythological three-tiered or three-storied cosmological view of up-above, here-below and down-under are likely to run into trouble (cf. Mathewson 2003:244). Minear (1962:23) warns against oversimplified reconstructions of the New Testament cosmology, which rather reflects modern western cosmological views than that of the Bible. In biblical texts, and especially in apocalyptical texts such as Revelation, categories such as heaven, earth and sea mostly 'play havoc with temporal and spatial calculations' (Minear ibid:32).

Due to the very nature of the 1st century's apocalyptic writings, scholars are becoming more and more aware that Revelation should not be approached from the traditional historical-critical angle, but rather be studied as a text of symbols and metaphors. Accordingly, the book has recently been subjected to narrative and rhetoric-critical analyses (e.g. Resseguie 1998; Barr 2006) and various studies of the metaphors and imagery in the book have been made (e.g. Räpple 2004; Labahn 2011). This article is meant as a similar attempt with a specific focus on the 'cosmological phrases' in Revelation as expressions of metaphoric language, thereby providing a basis for evaluating the traditional worldview assumptions.

For this purpose, the method developed by Van der Watt in his study of metaphors in the Gospel of John (Van der Watt 2000) is broadly followed. This means that the study is conducted as a deductive investigation into the way in which the author of Revelation uses and applies his own metaphors (cf. Van der Watt ibid:5). In the investigation, the following terms are employed, as suggested by Van der Watt (ibid):

1. Focus (the word that does not make sense when taken literally; also referred to as 'vehicle') and frame (the context that causes it to not make literal sense, also referred to as 'tenor') in every metaphoric utterance.

2. Different types of metaphors that are to be distinguished, such as surface metaphors (in which the focus and frame are both present in the microscopic context), suspended metaphors (in which the frame comes from the macroscopic context), and composite metaphors (in which focus and frame are linked only from a broader context, even broader than the book itself). (pp. 17-21)

\section{Survey: Cosmos, heaven, earth and sea as cosmologic references}

A logical place to start a deductive investigation of cosmology in Revelation is the use of the word кó $\sigma \mu$ o $\zeta$ in the

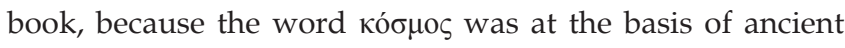
cosmology - not only etymologically, but also materially (cf. Adams 2008:6). ${ }^{2}$ A quick survey indicates that the word established as the technical term for the universe.

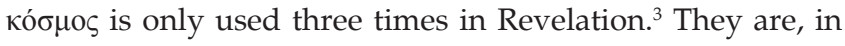
order of appearance:

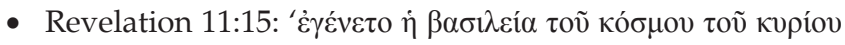
$\dot{\eta} \mu \tilde{\omega} v^{\prime}$ [The kingdom/reign of the world has become that of our Lord].

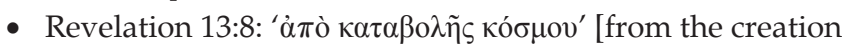
of the world].

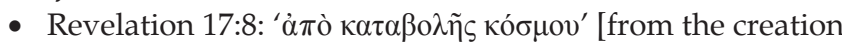
of the world].

In the last two of these three passages (Rev 13:8; 17:8), there

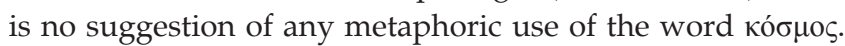
In both passages it forms part of a temporal phrase in which

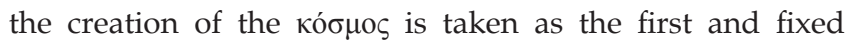
point of time. So the frame within which the word is used points at a literal understanding in spatial sense. Kó $\sigma \mu \boldsymbol{s}_{\text {, }}$ in both instances, refers to God's creation in its totality, ${ }^{4}-$ the universe, but still without any reference to its cosmic order (Sasse 1985:462).

The remaining passage, Revelation 11:15, which speaks of God's restored kingdom over the кó $\sigma \mu \mathrm{s}$, places the word

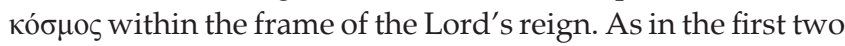
passages, кó $\sigma \mu$ o $\varsigma$ here is definitely applied in the literal sense, once again in reference to God's entire creation in spatial sense, whilst it views the entire creation as unity, including heaven and earth (Osborne 2002:441). Although not used as metaphor, it seems that a qualitative and temporal aspect is added to the sense of the word within this framework. Qualitatively, the кó $\sigma \mu$ o $\varsigma$ is regarded as being subject to the Lord's reign. In the temporal sense, the restored reign of God supposes that God was Lord of his entire creation from the beginning, but that it was alienated from its Creator over time - however, his rightful reign will be restored in the end (cf. Sasse 1985:462). This observation suggests a possible aspect of the cosmology of Revelation that has to be tested in the investigation below, namely that the restoration of God's reign over the кó $\mu_{0} \varsigma$ is at the basis of Revelation's cosmology.

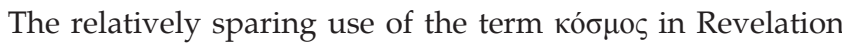
may be explained by the fact that John, in his visionary descriptions, mostly depicts the created universe according to its constituent parts, namely heaven, earth and sea (Beale

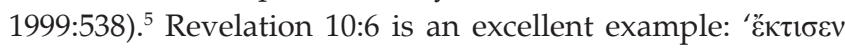

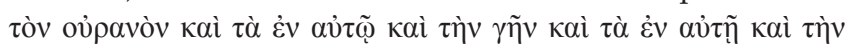

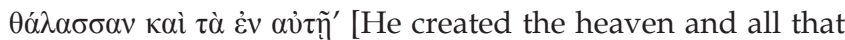
is in it, and the earth and all that is in it, and the sea and all that is in it].

3.The fact that it occurs only three times in Revelation is in striking contrast to the frequent use of kó $\sigma \mu \mathrm{o}$ in the other Johannine writings: no less than 78 times in the Fourth Gospel, 22 times in 1 John, and once in 2 John. Yet, in these other writings,

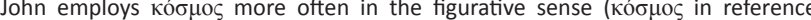

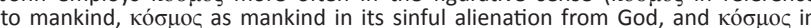
reference to the ol'am hazzeh [this dispensation after the fall]; (cf. Moulton \& Geden 1978:556-557; Coetzee 1995:32-33). From its use in the other Johannine writings, it can be expected that kó $\sigma$ uoc is also used in the figurative sense in Revelation it can be expected that $\kappa o \sigma \mu{ }_{0} \zeta$ is also used in the figurative sense in Revelation Revelation John rather employs the terms oủpavóc, $\gamma \tilde{\eta}$ and $\theta \alpha \dot{\lambda} \lambda \alpha \sigma \sigma \alpha$.

4.Exactly the same phrase occurs in John 17:24 - in the very same sense.

5.Or, vice versa, the total of the constituent parts (heaven, earth and sea) may refer to the cosmos in its totality (cf. Beale 1999:538). 
The threefold depiction of heaven, earth and sea in Revelation 10:6 stresses all spheres of life in this world, and thus everything of which God is creator and over which he is sovereign (Osborne 2002:399). This triad is repeatedly found in some form or another throughout Revelation:

- Heaven, earth and sea: found six times in Revelation 5:3, $13 ; 9: 1 ; 10: 6 ; 14: 7 ; 21: 1$.

- Heaven and earth: found three times in Revelation 6:13; 20:11; 21:1.

- Sea and earth: found seven times in Revelation 7:1, 2, 3; $10: 2,5,8 ; 12: 12$.

By describing the created universe in terms of heaven, earth and sea, John seems to relate to the ancient Jewish views of the cosmic order as a system of spheres: notably heaven and earth, with the sea or the underworld as a third sphere (Sasse 1985:463; Osborne 2002:264; Aune 2006:51-52). In the Old Testament such a three-level structure of the creation is often presumed as phrased in Exodus 20:4: '[A]nything in heaven and on earth and in the water under the earth' (McDonough 2008:183).

It has to be kept in mind, however, that in the Bible, time and space are not always viewed as two separate and even opposing categories. Equally, time is not regarded in the Biblical texts as unilinear and space as a one-dimensional measure as if time and space are all-inclusive categories outside of which nothing is real (Minear 1962:23). In addition to these considerations, the possibility of the metaphoric use of the triad heaven, earth and sea in Revelation should be considered.

How does John use the terms heaven, earth and sea in his book of Revelation? The following may be observed when looking at each of these terms separately (cf. also McDonough 2008:180ff.).

\section{Heaven (oủpavós)}

There are some instances in Revelation where oủpavóc [heaven] is used within a 'normal', familiar frame without any strangeness of reference. In such instances oủpavós primarily means the visible sky, the place of meteorological phenomena. In most instances by far, however, oủpavós is placed in a frame where it cannot be understood literally as a phenomenon that is visible to the normal eye (cf. Labahn 2011:111).

\section{Heaven as the visible sky}

In Revelation a number of passages refer to the oủpavó [sky] within the frame of a literal description, where oủpavó to be understood as the physical space in the air where the stars appear at night ( $\operatorname{Rv} 6: 13 ; 8: 10 ; 9: 1 ; 12: 4$; cf. Kistemaker 2004:237, 276). In some other passages it is also presented as the source of meteorological phenomena, such as rain ( $\mathrm{Rv}$ 11:6) and hail ( $\operatorname{Rv} 16: 21)$ falling on the earth. Yet, it has to be kept in mind that these phenomena are all described as part of the visions that John saw. This is especially the case in Revelation 13:13 where the beast is said to cause fire coming from the sky, and in Revelation 20:9 where God sends fire from heaven (the sky), bringing doom to the idolatrous earth-dwellers (McDonough 2008:180). In passages such as this, the line between literal and figurative language is so thin that it is difficult to say whether it should be taken as a metaphor (cf. Van der Watt 2000:24). However, whether literal or figurative, these instances do not present the sky as part of a cosmology, but simply refer to the sky as the normal physical phenomenon as seen by people of all time.

A more complex example is Revelation 12:4, where John describes a third of the stars being swept from heaven (the sky) by the dragon's tail. This passage has an interesting interplay between its literal and figurative sense. The frame of the narrative is that of a description of phenomena that John saw in his vision. Within this frame, oujpavó $̧$ is presented as the physical sky with real stars, so that some scholars maintain that the heaven and the stars in this passage still relate to meteorological phenomena as part of God's creation (e.g. Van de Kamp 2000:290). ${ }^{6}$ Even if one would interpret these stars in the physical sense, referring to real stars in the sky, the entire narrative is nevertheless so out of the ordinary that it presents itself as visionary, making use of symbolic language. The stars in this passage are understood figuratively by most commentators as references to the (fallen) angels (e.g. Greijdanus 1925:252; Beale 1999:636; Osborne 2002:461; Kistemaker 2004:357). As such, this passage is an example of a composite metaphor of which the frame is to be found not in the micro- or macroscopic context, but as far removed as the Old Testament - in the apocalyptic material of Daniel 8:10-12 (cf. Beale 1999:635-636). Within this context, the oujpavós [heaven] is more than the physical sky above; it becomes a metaphor for the dwelling place of God, which leads us to the next point.

\section{Heaven as the dwelling place of God}

In Revelation 4:1 (and likewise in $\mathrm{Rv}$ 19:11), John sees an open door in heaven. Again, taking into account the interplay between the literal and the figurative in John's visions, the vision in these passages is obviously metaphoric in sense. The element that seems out of place in this vision is not the heaven that John saw, but the open door in it - the focus of the sentence is the door, and heaven is part of the frame. Yet, the rest of the description in chapter 4 brings forward the metaphoric sense of oujpavó in this passage. From verse 2 onward it becomes clear that heaven does not refer to the physical sky above, but to the dwelling place of God. The door in heaven gives access to a place where God is: in his heavenly temple (cf. Rv 11:19; 14:17; 15:5; 16:17), sitting in glory on his throne (cf. Rv 4:2-10; 5:1-13; 6:16; 7:9-17; 8:3; 12:5; 14:3, $5 ; 19: 4,5 ; 20: 11 ; 21: 5 ; 22: 1,3)$. Likewise, in Revelation 19:11, heaven refers to what can be called the celestial dwelling place of God. Moving on to the larger macroscopic context, heaven as God's dwelling place becomes visible in John's visions not only through the open door of Revelation 4:1 and 19:11, but also on the day of wrath when the sky is seen rolling back like a scroll $(\operatorname{Rv} 6: 14)$.

$6 . V a n$ de Kamp (2000:290) understands this passage as the dragon attempting to ruin God's physical creation, including the stars. 
This portrayal of the oủpavós as God's heavenly dwelling place seems to correspond to the ancient Jewish naïve cosmology of the earth 'here-below', with the sky being the 'roof' of the visible world and at the same time the 'floor' of the divine throne room in heaven (cf. McDonough 2008:181; Aune 1998:279). John's vision of a 'sea of glass, clear as crystal' before God's throne ( $\operatorname{Rv} 4: 6)$ also seems to relate to the ancient view of a massive dome of suspended water

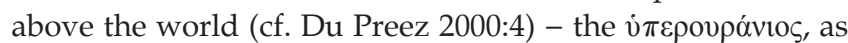
Plato would call it (McDonough ibid:181).

However, the ancient cosmology does not entirely fit John's description in Revelation - there are some striking differences.

Firstly, the 'throne room', as John describes, is not spatial in the true sense of the word. In John's description of God's celestial dwelling place, the categories of time and space seem to be mingled (cf. Minear 1962:23). Right from the outset it becomes clear that the heavenly dwelling place of God in Revelation has a definite temporal aspect attached to it. In Revelation 4:1, John is invited through the open door in heaven by the words: 'Come up here, and I will show you what must take place after this'. John, from his elevated position in heaven, receives a bird's eye view not as much of the entire world 'below' (covering all space), but rather of God's future plan for his creation (covering all time). Hence, Beale (1999:319) concludes that heaven in Revelation 4:1 does not refer to God's heavenly dwelling place or abode, but rather to his heavenly council. God's heavenly council covers all time - not only the future, but also the present (Kistemaker 2004:184), and even the past in as far as present and past are interrelated. This becomes evident from the macroscopic context of Revelation, for example in Revelation 1:19, where John is commissioned to write down 'what is now and what will take place later' - an instruction from the Lord 'who is, and who was, and who is to come' (Rv 1:8). Thus, in contrast to ancient cosmology, heaven as God's dwelling place is not presented in Revelation as a place being elevated above the physical world as much as it is a divine point above time and even above the entire history (cf. Labahn 2011:133-134).

The macroscopic context of oủpavó in Revelation 4 can be explored even further. From his heavenly throne, God not only overviews the entire history, but also determines it (cf. his 'heavenly council' in Beale 1999:319; cf. Kistemaker 2004:184; McDonough 2008:181; Labahn 2011:135). It is not, as the popular song goes, as if 'God is watching us from a distance'. No. From his heavenly throne, God is actively involved in what happens in history - and even his involvement is not as if, in a semi-deistic sense, 'from a distance'. On the contrary - in John's visions, he repeatedly hears voices from heaven speaking on the earth about things that are happening or should happen on earth (e.g. Rv 10:4, 8; cf. Osborne 2002:402; Rv 11:12, 15; 12:10; 14:2, 13; 18:4; 19:1; 21:3). Even more important is the fact that Revelation reveals that God's determinative plan for the world history is put into action by his own divine work on earth, through his Son (cf. Kistemaker 2004:207). His Son came into this world as a Lamb, as if slain ( $\operatorname{Rv} 4: 6)$, all as part of the divine plan to establish God's kingdom on earth (McDonough 2008:182). Having set God's plan into action, the Lamb is seen in Revelation 5:6 at the centre of God's throne in heaven, from where he is directly involved in every new development in world history - in control of God's unfolding plan for this world (Rv 6:1-6; cf. Osborne 2002:272). Thus, the heavenly involvement in what happens on earth ensures that the 'distance' between the 'heaven above' and the 'earth below', as often viewed in ancient cosmology, is narrowed down to the point where it almost disappears.

The fact that the categories of space and time are joined in heaven as God's dwelling place can be seen at the eschaton. At the eschaton, in the end of time, God's throne does not remain in heaven, but descends with the holy Jerusalem to be on earth ( $\operatorname{Rv} 21: 3-5 ; 22: 1-3)$. Already in Revelation 4 it becomes clear that God's heavenly throne room is 'a kind of archetype of the eschaton' (McDonough 2008:182). The throne room, as depicted in chapter 4 , provides all the constituent elements of the New Jerusalem of chapter 21. In fact, chapter 4 and chapter 21 structurally form a striking inclusio pattern (cf. Beale 1999:320-321):

- In chapter 4, John's vision takes him from earth to heaven where he witnesses God's throne in his heavenly abode, decorated with jasper and carnelian, surrounded by a rainbow-like emerald, looking out over a sea of glass, clear as crystal.

- In chapter 21, John witnesses the New Jerusalem coming down from heaven, clear as crystal in its brilliance, decorated with jasper, sapphire, emerald, carnelian and other precious stones. God's dwelling place in Revelation 21 and 22 is henceforth on the new earth, amongst his people. Any notion that Revelation features a cosmology of an unbridgeable spatial distance between God's celestial dwelling place and the earth down here below is countered in these last chapters of the book.

In summary, being part of apocalyptic revelations in Revelation 4, oúpavós as the place of God's throne, is metaphoric for God's sovereign reign over the entire universe and his divine council for the world history of all time (Raber 1986:297; Beale 1999:319; Kistemaker 2004:185). Likewise, the celestial abode does not refer to a physical building, but represents God's covenant of grace that is coming into fulfilment (Van de Kamp 2000:474). Therefore, heaven as God's dwelling place, should be regarded as more than a physical space above the clouds. Although it is not a 'no-place', it is a place that transcends the spatial and the temporal limits of our rational minds. And yet, it is not isolated from the 'world below', but, in the person of the Lamb, heaven is directly and actively involved in the matters of the world - in time and space.

\section{Heaven as place of obedient worship to God}

In the vision of chapter 4, God's throne is seen surrounded by 24 elders, and four living creatures, all giving praise to him on the throne, day and night. Again, the frame of this 
description bears some strangeness so obvious that there can hardly be any doubt about its figurative sense. Again, the micro- and macroscopic contexts do not provide the required frame for understanding the metaphoric sense of the 24 elders and the four living creatures. Therefore, the metaphor is a composite metaphor of which the frame is a distant link. Linked to the general composition of the Old and the New Testament, the traditional understanding of the 24 elders in the vision is that they should be taken as a symbol (cf. Van der Watt 2000:1-4) for the 12 tribes of Israel and the 12 apostles (Kistemaker 2004:187). Whether this view holds truth or not, it can at least be accepted from the microscopic context of Revelation 4 that they represent the believers of all time (Kistemaker ibid:188). They are washed pure from all sin by the blood of the Lamb, says Revelation 7:14, and 'they are before the throne of God and serve him day and night'. Their song of praise is for the saints of all time, including the saints of the Old and the New Testament. Therefore, in Revelation, heaven is where God is served and worshipped by all who are clean from sin, cleansed by the blood of the Lamb.

Numerous hypotheses about the interpretation of the four living creatures of Revelation 4 have been suggested. Once again, the micro- and macroscopic context do not provide an interpretation key, so that it has to be taken from a distant passage, of which Ezekiel 1:5-22 and Isaiah 6 seem to be the most obvious (cf. Beale 1999:328). The most viable interpretation option, which has the least tendency to allegorise, is that the four living creatures represent the entire animate creation of God (cf. Osborne 2002:233-234). The entire animate creation, just as the believers of all time, gives praise to God before his throne without end. It can therefore be said that heaven in Revelation 4 is presented by these metaphoric portrayals as the place where God is praised in worship and obediently served as the Lord of all and everyone. Thus, it proves that heaven in Revelation once again receives an attribute that goes beyond the categories of time and space. Heaven is a qualitative reference to a situation where all and everyone live in God's presence, in ceaseless praise, worship and obedience to him as Lord.

Still within the metaphor of heaven as the qualitative situation of God's presence where he is praised, worshipped and obeyed, comes Revelation 12. Chapter 12 tells us that Satan and his powers were hurled down from heaven after a primordial struggle. They had 'lost their place in heaven' ( $R v$ 12:8), for heaven has no place for those who rebel against God and refuse to obey him. ${ }^{7}$ The cosmological aspects of this power struggle in heaven between the angelic forces and the evil forces call for further investigation that is not addressed in this article. However, it should be noted that it is not a war between 'above' and 'below', but it sets out as a struggle in heaven, and only then does it become a war that is continued on earth (Beale 1999:656), albeit within the limits set by God (Kistemaker 2004:362). The celestial battleground becomes a terrestrial battleground, leading to the final judgment in Revelation 19.

7.Satan and his powers being cast down from heaven (cf. Lk 10:18; In 12:31) are explained by Osborne $(2002: 471)$ as taking place in three stages: at their original rebellion, at the death and resurrection of Christ, and in their final destruction in the lake of fire.
Also in this respect, heaven becomes a kind of archetype of the eschatological New Jerusalem, for in Revelation 21:27 we read that in the eschaton 'nothing impure will ever enter the Holy City, nor will anyone who does what is shameful or deceitful'.

\section{Earth $(\gamma \tilde{\boldsymbol{\eta}})$}

The second constituent part of the created universe as phrased in Revelation, is the earth (cf. $\mathrm{Rv} 10: 6$ ). As part of God's physical creation, the earth is good, since it was created to give glory to God ( $\operatorname{Rv} 5: 13$ ). John's descriptions of the earth in general seem to fit into the ancient Jewish views of the cosmic order, as a physical place 'here-below', the place where rain ( Rv 11:6), hail (Rv 16:21) and even stars (Rv 6:13) fall when they come down from heaven (cf. Osborne 2002:251). In Revelation 7:1 John speaks of the four corners of the earth which could be regarded as in line with how that ancient society and hence also John and his readers, pictured the shape of the world (cf. Osborne ibid:305). However, this description of the earth does not necessarily mean that John adopted any given cosmology of his time. It only tells us that when he wrote, he used terms and images that were wellknown to him and his readers, and were hence appropriate for good communication (McDonough 2008:179).

In Revelation earth $(\gamma \tilde{\eta})$ is often named as the dwelling place of people, the inhabitants of the earth. In Revelation 6:10, 8:13, $11: 10,13: 8,12,14$ and 17:2, 8, the earth dwellers are referred to

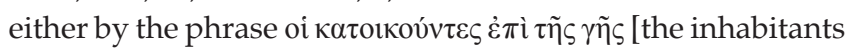
of the earth] or by the phrase $\dot{\eta}$ oikov $\mu \varepsilon \dot{v} \eta$ [the inhabited world]

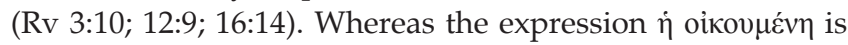
sometimes used in a context where it has a universal sense, literally referring to all people dwelling on earth (cf. Beale

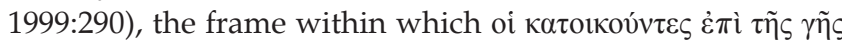
is used in Revelation is always such that the phrase can be taken as a metaphoric expression specifically designating the unbelievers - who have done wrong against the saints $(\mathrm{Rv}$ 6:10), who worship the beast ( $\operatorname{Rv} 13: 8)$ and who will be under God's judgment (Rv 8:13; cf. Osborne 2002:193). Within this very same framework, the word $\gamma \tilde{\eta}$ in Revelation often has a sense that goes beyond its literal meaning of the physical world. Almost without exception, it has a qualitative reference. In contrast to heaven, earth in John's visions has a strong negative association, metaphorically speaking of all that are unfaithful to God. ${ }^{8}$

In Revelation 13, for example, the earth, true to its symbolism of ungodliness, is portrayed as the source from which the beast appears. The beast from the earth is of course Satan's mockery of the Son of Man who came into this world. But since the beast rises from the earth ( $\dot{\varepsilon} \kappa \tau \tilde{\eta} \varsigma \gamma \tilde{\eta} \varsigma)$, he is the ultimate manifestation of evil and blasphemy and hostility against God. The macroscopic context of chapter 12 teaches that earth $(\dot{\eta} \gamma \tilde{\eta})$ is also the place where Satan and his angels (the fallen stars of $\mathrm{Rv} 12: 4)$ find themselves after they were hurled down from heaven to earth. Once on earth,

8.Similar to the use of kóruos in the Fourth Gospel and in 1 John - in metaphorical sense of sinful humankind and this dispensation that is against God's kingdom (cf. Coetzee 1995:32-33). 


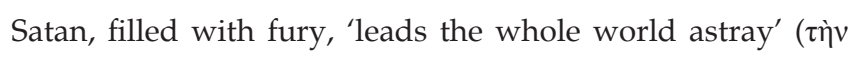

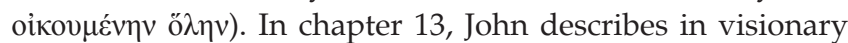
language how Satan launches his misleading of the world by the appearance of the beast (cf. Bauckham 2005:185-186).

Thus, in the visions of Revelation, the earth becomes a metaphor for sinful mankind who is in the power of evil under the rule of Satan.

This does not mean, however, that there is no place for the church on earth. Since the earth $(\gamma \tilde{\eta})$, even in this sinful dispensation, remains part of God's creation and hence under his divine authority $(\operatorname{Rv} 10: 1-2),{ }^{9}$ it still is a place of refuge for the church under persecution. In Revelation 12, the church, metaphorically depicted as a woman, is aided by the earth, when the earth swallows the river that the dragon, i.e. Satan, sends after the woman (Labahn 2011:123). The frame within which $\gamma \tilde{\eta}$ becomes the focus of Revelation 12:15 is entirely different from that of chapter 13. In Revelation $12: 15$, the earth is a tool in the hand of God to deliver his people from the onslaught of Satan (cf. Osborne 2002:484). As composite metaphor, the interpretation framework for earth in Revelation 12:15 may be taken from the Song of Moses in Exodus 15:12, to which Revelation 12:15 probably is an allusion. In Exodus 15:12, the drowning of the Egyptians is praised: 'You stretched out your hand and the earth swallowed them' (cf. Osborne ibid:484). Consequently, earth $(\gamma \tilde{\eta})$ in Revelation 12:15 may be taken as a metaphor for God's act of preserving and saving his church in times of persecution.

However, in spite of the occasional exceptions as in Revelation $12: 15$, earth $(\gamma \tilde{\eta})$ in the visions of Revelation is mostly used as metaphor for sinful mankind, who is in the power of evil under the rule of Satan.

\section{Sea $(\theta \alpha ́ \lambda \lambda \alpha \sigma \sigma \alpha)$}

As in the case of earth, the sea $(\theta \alpha \dot{\lambda} \alpha \sigma \sigma \alpha)$ is often used in Revelation within a context where it has a more or less literal reference. In such instances, sea refers to a body of water as part of creation (Rv 5:13; 7:1-4; 8:8-9; 10:2; 14:7; 16:3; cf. Beale 1999:1043). In Revelation 10:1-2, for example, the vision that John describes is that of an angel with his right foot on the sea and his left foot on the land. The vision itself, as indicated above, symbolises God's supreme reign over both land and sea, without any metaphoric sense intended for either land or sea (Kistemaker 2004:309).

However, the first reference to the sea in Revelation comes as part of the scene of the heavenly 'throne room' that John describes in chapter 4 . In Revelation 4:6, John sees before God's throne a 'sea of glass like crystal'. This reference to the sea obviously has a metaphoric sense and has led to a variety of interpretations (cf. Kistemaker 2004:189). Taking into account that the sea in Revelation, as indicated below, is generally used as metaphor for something negative, such as

9.The angel in Revelation 10:1-2 with his right foot on the sea and his left foot on the land, symbolises God's supreme reign over both. the source of evil, the sea before the holy throne of God does not seem to make any sense. In addition, the sea depicted before God's throne differs from its normal manifestation. Normally the sea is seen as a restless and perpetually moving mass of water. In Revelation 4:6, however, it is clear 'as crystal'. The description of a 'sea of glass, clear as crystal' would immediately have attracted the attention of the first readers, since glass in ancient times was opaque, whereas crystal was clear (cf. Kistemaker ibid:189). The strangeness of a clear and brilliant sea suggests metaphoric usage. Taken as a composite metaphor that links with Ezekiel 1:22 (Beale 1999:327), and within the frame of God's majestic appearance on his throne as described in Revelation 4, the crystal clear sea metaphorically speaks of the transcendence and majesty of God (Du Preez 2000:5).

At first sight, the sea in Revelation seems to be part of the ancient Jewish cosmological view of a three-level structure of the creation, being equated to the water under the earth' (Ex 20:4; cf. Osborne 2002:231). Scholars often equate John's portrayal of the beast rising from the sea ( $\operatorname{Rv} 13: 1)$ to the Jewish myth of Leviathan - the female monster from the sea - although the similarities are only superficial (cf. Aune 1998:728). The fact that the beast rising from the sea in Revelation 13:1 is seen in Revelation 11:7 and 17:8 as rising from the abyss ( $\dot{\alpha} \beta v 0 \sigma o c_{\text {; }}$ the 'bottomless pit'), made scholars, such as Bousset (1966:358), to understand the sea and the abyss in Revelation as identical. From this, it is only a small step to say that the sea in Revelation is equal to Hades. This view would perfectly fit the ancient mythological three-storied cosmological view of 'up-above', 'here-below' and 'down-under', as suggested by Bultmann (1966:15). However, the similarity between the sea and the abyss in Revelation is taken too far by scholars who regard them as identical. It has to be kept in mind that the beast rising from the sea and the beast rising from the abyss are two separate visions (Du Preez 2000:11), each with its own purpose.

On the other hand, Du Preez (2000) tends to separate the visions of the beast from the sea and from the abyss too much. According to him, the earth is pointing only towards the working terrain of the beast and the abyss to the origin of the beast (Du Preez ibid:11). However, there is not enough reason to separate the two in this manner. Although the sea and the abyss should not be equated entirely, both depict some aspect of the origin of the beast: the abyss, which was the prison house of the evil spirits according to Jewish traditions (McDonough 2008:183), is the place the beast originates from, whereas the sea is the place from which the beast makes his appearance. The sea depicts the sinful gathering of nations who, in the power of Satan, is constantly stirred to motion by their sinful nature, causing them never to come to rest, like the restless waves of the sea (Coetzee 1988:304).

To the readers of that time, the picture of the beast from the sea would also be a reminder of Rome with its imperial powers reaching out from across the sea (Beale 1999:682). The sea from which the beast is appearing therefore also depicts the evil powers that threaten the establishment of the 
Kingdom of God (Mathewson 2003:246). Therefore, the sea in Revelation 13:1 is part of the imagery and does not denote a physical space. It conveys to the readers the basic evil from which the beast originates (cf. Rv 12:18).

In addition to evil as origin, Beale identifies three other metaphoric uses of the sea in Revelation - all of these are negative in sense:

1. The nations that persecute the believers ( $R v$ 17:1-6).

2. The place of the dead ( $\operatorname{Rv} 20: 13)$.

3. The place of trade of idolaters.

Finally, it has to be noted that John sees a new heaven and a new earth in the eschaton, but not a new sea. In fact, Revelation 21:1 explicitly says: 'There was no longer any sea'. Commentators explain this passage in various manners (cf. Van de Kamp 2000:450; Adams 2007:239). Despite efforts to understand the disappearance of the sea as a physical description, in the sense that the sea 'no longer will exist with its present boundaries' (Kistemaker 2004:555), the strangeness of the depiction rather suggests metaphorical language. The interpretation as suspended metaphor that fits best to the metaphoric imagery of the sea elsewhere in the book, is that humanity in the new creation is morally purified (Du Preez 2000:13) and no longer threatened by the evil hidden powers, as symbolised by the sea (Van de Kamp ibid:450; McDonough 2008:184).

The disappearance of the sea in the eschaton is final proof that the sea in most passages in Revelation should not be calculated in spatial terms (cf. Minear 1962:32), since a physical disappearance of the sea would suggest that at least part of God's creation has failed and will be abolished completely at the eschaton. Instead, it seems probable that the sea as physical phenomenon will be part of the restored earth that appears in Revelation 21, together with the new heaven.

\section{The new heaven and new earth}

As part of God's good creation, the earth also has its place in God's plan of redemption. In the eschaton, John sees not only a new heaven, but also a new earth. The first heaven and first earth, he says in Revelation 21:1, had passed away. The point of his statement is not to give details about where the first heaven and earth have gone. Contrary to the understanding of Adams (2007:238), John is not saying in this passage that God has simply wiped everything away to begin again with nothing (Heide 1997:41). As in the rest of Revelation, this vision should be taken metaphorically - in temporal and qualitative, rather than in physical sense. It does not say that the physical world will be destroyed, nor does it mean that God will replace his creation by a new one. If so, it would mean that God's creation has failed (Heide ibid:43).

Revelation 21 is saying that in the eschaton the earth as part of God's creation will be made new (кaiví) - renewed, as the

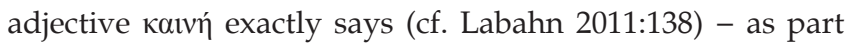

of a prophetic fulfilment (Beale 1998:112-113). Although this renewal would certainly include a physical transformation (Kistemaker 2004:555), the focus of chapter 21 is entirely on a qualitative transformation (Osborne 2002:729; Adams 2007:256). This qualitative transformation is described in Revelation 21:4: 'There will be no more death or mourning or crying or pain, for the old order of things has passed away.' The 'old order of things that has passed away' is depicted in verse 1 of the chapter as the sea no longer having any place on the new earth. This qualitative renewal is also reflected in the Holy City, which will come down from God ( $\operatorname{Rv} 21: 2$, 10), for in Revelation 21:27 we read that nothing impure will enter it. The intertextuality with Old Testament prophecies, in particular Zechariah 8:3, 12:1-9 and 14:1-11 (cf. Osborne ibid:732), provides the frame for understanding Revelation 21:4 as a composite metaphor.

The most important quality of the new heaven and the new earth is described in Revelation 21:3: 'Now the dwelling of God is with men, and he will live with them. They will be his people, and God himself will be with them and be their God.' These words so closely echo the covenantal language of the Old Testament (e.g. Gn 9:15-17; 12:3; 17:4-6) that the new earth can thereby be taken as portrayal of the fulfilment of God's promise in his covenant of grace. The first fulfilment of the covenantal promise was the coming of Jesus Christ as Immanuel [God with us] into this world; the final fulfilment is in the eschaton as depicted in Revelation 21. Therefore, these last chapters of the book become the final meeting point of the lines of God's covenant - from beginning to end, from the Old to the New Testament (cf. Kistemaker 2004:557). It is the climax of the New Covenant where God finally dwells with his people in the new heaven and earth.

Past, present and future once again come together in Revelation 21.

\section{Conclusion}

It is clear from the above that, although John in Revelation refers to heaven, earth and sea as the three basic components of the creation, he does not thereby subscribe to the threestoried cosmology so typical to the ancient worldview, nor does he present any cosmology in the normal sense of the word. Rather, he tends to use heaven, earth and sea in a metaphoric sense that 'clearly transcended man's definition of space. Certainly we cannot accuse him of holding a naïve three-storied idea of the physical world' (Minear 1962:34).

Time and space become so intermingled in the visions of Revelation that it is unlikely that any systematic cosmology can be derived from the visions of Revelation (Minear 1962:33). Rather, the heaven, earth and sea are described in metaphoric terms with a distinctive qualitative sense. Heaven, as the dwelling place of God in the eschaton, is portrayed as coming to earth. The new heaven and the new earth is a qualitative description of God making his tabernacle with the believers, finally coming to dwell with his people in his covenant of grace as promised from the beginning. 
This last conclusion brings us back to the very first reference

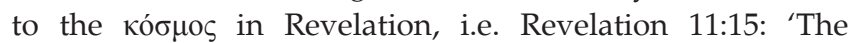

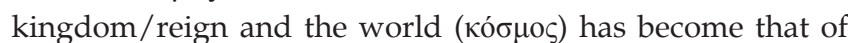
the Lord.' These words prove to be the outcome of the visions of Revelation. The visions in metaphoric language tell of the restoration of God's divine reign and authority over all and everything. His reign is an eternal reign; his authority is unchanged above all. Yet, both are challenged by Satan, the rebel king. In the end, however, God's reign and authority is restored and acknowledged above all doubt throughout the

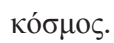

This, to my mind, is the very essence of the cosmology in Revelation.

\section{Acknowledgements Competing Interest}

The author declares that he has no financial or personal relationship(s) that may have inappropriately influenced him in writing this article.

\section{References}

Adams, E., 2007, The stars will fall from heaven: Cosmic catastrophe in the New Testament and its world, T\&T Clark, London. (Library of New Testament Studies, no. 347).

Adams, E., 2008, 'Graeco-Roman and ancient Jewish cosmology', in W. Klassen \& G.F. Snyder (eds.), Current Issues in New Testament Interpretation, pp. 5-27, SCM Press, London.

Aune, D.E., 1998, Revelation, Word Books, Dallas. (Word Biblical Commentary).

Aune, D.E., 2006, 'Apocalypse renewed: An intertextual reading of the Apocalypse of John', in D.L. Barr (ed.), The reality of the Apocalypse: Rhetoric and politics in the book of Revelation, pp. 47-68, SBL, Atlanta, (SBL Symposium Series, no. 39).

Barr, D.L., 2003, Reading the book of Revelation: A resource for students, SBL, Atlanta. (SBL Resources Series, no. 44).

Barr, D.L. (ed.), 2006, The reality of Apocalypse: Rhetoric and politics in the book of Revelation, SBL, Atlanta. (SBL Symposium Series, no. 39).

Bauckham, R., 2005, The climax of prophecy: Studies in the Book of Revelation, T\&T Clark, London/ New York.
Beale, G.K., 1998, John's use of the Old Testament in Revelation, Academic Press, Sheffield. (JSNT Supplement Series, no. 166).

Beale, G.K., 1999, The book of Revelation, Eerdmans, Grand Rapids. (New International Greek Testament Commentary).

Bousset, W., 1966, Die Offenbarung Johannes, rev. edn., Vandenhoeck \& Ruprecht, Göttingen. PMid:5178911

Bultmann, R., 1966, Jesus Christ and Mythology, SCM Press, London.

Coetzee, J.C., 1988, 'Die prediking (teologie) van die Openbaring van Johannes', in A.B. du Toit (ed.), Handleiding by die Nuwe Testament, vol. 6., pp. 253-314, NG Kerkboekhandel, Pretoria.

Coetzee, J.C., 1995, Keys to God's revelation in the New Testament, EFJS Uitgewers, Orkney. PMCid:PMC177115

Du Preez, J., 2000, 'Die rol van die see in die Patmos-visioene', Acta Theologica $2000(2), 1-20$

Greijdanus, S., 1925, De openbaring des Heeren aan Johannes, Kok, Kampen. (Korte verklaring der Heilige Schrift).

Heide, G.Z., 1997, 'What is new about the new heaven and the new earth? A theology of creation from Revelation 21 and 2 Peter 3', Journal of Evangelical Theological Studies 40(1), 37-56.

Kistemaker, S.J., 2004, Revelation, Baker, Grand Rapids. (New Testament Commentary).

Labahn, M., 2011, '"Apokalyptische" Geographie', in M. Labahn \& O. Lehtipuu (eds.), Imagery in the book of Revelation, pp. 107-144, Peeters, Leuven. (Contributions to Biblical exegesis \& theology, no. 60).

Mathewson, E., 2003, "New Exodus as a background for "the sea was no more" in Revelation 21:1c', Trinity Journal 24(2003), 243-258.

McDonough, S.M., 2008, 'Revelation - The climax of cosmology', in J.T. Pennington \& S.M. McDonough (eds.), Cosmology and New Testament Theology, pp. 178-188, T\&T Clark, London/ New York. PMid:18054447

Minear, P.S., 1962, 'The cosmology of the Apocalypse', in W. Klassen \& G.F. Snyder (eds.), Current issues in New Testament interpretation, pp. 23-37, SCM Press, London.

Moulton, W.F. \& Geden, A.S., 1978, A concordance to the Greek Testament, T\&T Clark, Edinburgh.

Osborne, G.R., 2002, Revelation, Baker, Grand Rapids. (Baker Exegetical Commentary on the New Testament).

Raber, R.W., 1986, 'Revelation 21:1-8', Interpretation 40(3), 297-301.

Räpple, E.M., 2004, The metaphor of the city in the Apocalypse of John, Peter Lang, New York. (Studies in Biblical Literature, no. 67).

Resseguie, J.L., 1998, Revelation unsealed: A narrative critical approach to John's Apocalypse, Brill, Leiden. (Biblical Interpretation Series, no. 32).

Sasse, H., 1985, 'Kosmos', in G. Kittel \& G. Friedrich (eds.), Theological Dictionary of the New Testament, transl. G.W. Bromiley, pp. 459-465, Eerdmans, Grand Rapids.

Van de Kamp, 2000, Openbaring: Profetie vanaf Patmos, Kok, Kampen. (Commentaar op het Nieuwe Testament, derde serie).

Van der Watt, J.G., 2000, Family of the King: Dynamics of metaphor in the Gospel according to John, Brill, Leiden. (Biblical Interpretation Series, no. 47). 